"Quality of working life and inequality: gender consideration"

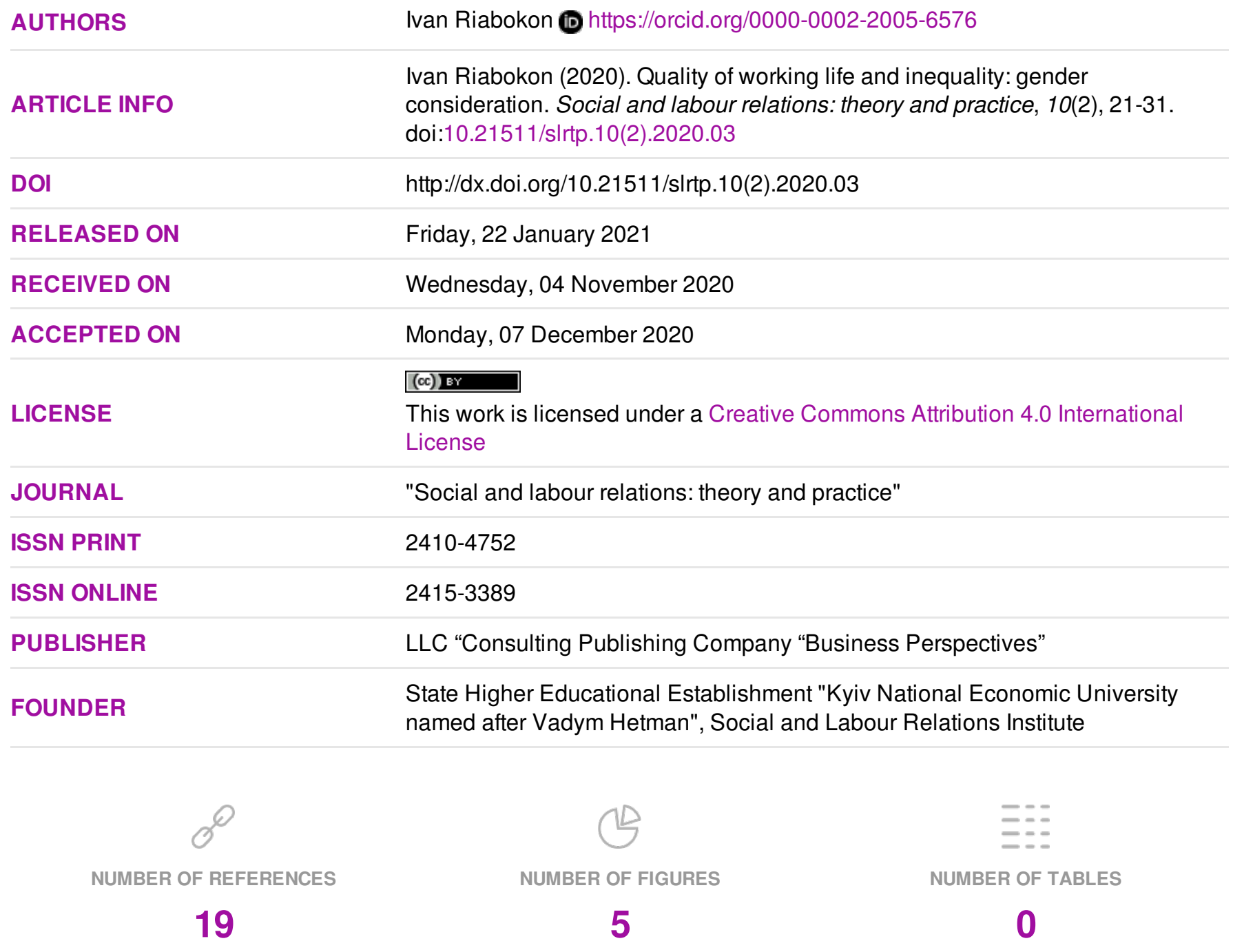

(C) The author(s) 2021. This publication is an open access article. 


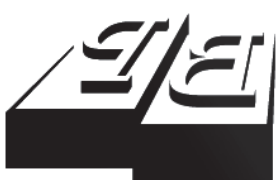

BUSINESS PERSPECTIVES

Publisher

LLC "CPC "Business Perspectives" Hryhorii Skovoroda lane, 10, Sumy, 40022, Ukraine www.businessperspectives.org

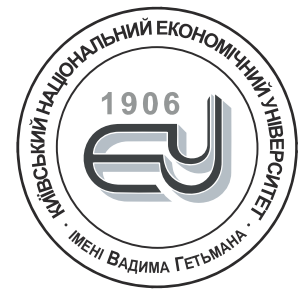

\section{HETMAN KNEU}

Founder

State Higher Educational Establishment "Kyiv National Economic University named after Vadym Hetman",

Prospect Peremogy, 54/1,

Kyiv, 03057, Ukraine

https://kneu.edu.ua/

Received on: 4th of November, 2020 Accepted on: 7th of December, 2020 Published on: 22nd of January, 2021

(ㄷ) Ivan Riabokon, 2021

Ivan Riabokon, Ph.D. Student, Personnel Management and Labour Economics Department, Kyiv National Economic University named Vadym Hetman, Ukraine.

\title{
QUALITY OF WORKING LIFE AND INEQUALITY: GENDER CONSIDERATION
}

\begin{abstract}
The paper explores the impact of gender inequality on the quality of working life and analyzes the processes and factors that shape gender issues in Ukraine. The aim of the study is to assess gender inequality in the process of labor potential and human capital implementation, develop measures that would solve gender inequality problems in employment, and justify the positive impact of the proposed measures on the quality of working life. To achieve the abovementioned goal, statistical data and public opinion polls, which formed the basis of the proposed methods for solving the identified problems, have been analyzed. Determinants of gender inequality have been identified, the main of which are the gender wage gap, gender structure of employment imbalance, inequality of women's access to decent work due to gender stereotypes, and imperfect control mechanisms for gender-sensitive statistics. Possible approaches of the state's gender policy to achieve gender balance have been identified and expanded through a set of measures that would include improving the mechanism for controlling gender-sensitive statistical data in the form of monitoring at the organizational and state levels, budget planning with due consideration of gender dimension. The author's vision of the content and essence of gender policy at the institutional level in the context of transformation of values and gender culture of society has been shared.
\end{abstract}

\section{Keywords}

JEL Classification gender inequality, quality of working life, gender segregation, gender discrimination, gender stereotypes

\section{I. О. Рябоконь (Україна)}

\section{ЯКІСТЬ ТРУДОВОГО ЖИТТЯ І HЕРІВНІСТЬ: ГЕНДЕРНИЙ АСПЕКТ}

\section{Анотація}

У статті досліджено вплив гендерної нерівності на якість трудового життя, проаналізовано процеси і фактори, що формують гендерні проблеми в Україні. Метою дослідження є оцінка гендерної нерівності в процесі реалізації трудового потенціалу та людського капіталу, розробка заходів щодо вирішення проблем гендерної нерівності у сфері зайнятості і обгрунтування позитивного впливу запропонованих заходів на якість трудового життя. Для досягнення поставленої мети використано аналіз статистичних даних та опитування громадської думки, які лягли в основу запропонованих методів вирішення виявлених проблем. Визначено детермінанти гендерної нерівності, основними з яких $є$ гендерний розрив в оплаті праці, дисбаланс гендерної структури зайнятості, нерівність можливостей доступу жінок до гідної праці через гендерні стереотипи суспільства, недосконалість механізмів контролю гендерно-чутливих статистичних даних. Визначено і розширено можливі напрямки гендерної політики держави для досягнення гендерного балансу через комплекс заходів, що включатимуть вдосконалення механізму контролю гендерно-чутливих статистичних даних у формі моніторингу на рівні організацій та на державному рівні, бюджетне планування 3 урахуванням гендерних аспектів. Запропоновано власне бачення змісту і сутності гендерної політики на інституційному рівні в розрізі трансформації цінностей та гендерної культури суспільства.

Ключові слова

Класифікація JEL гендерна нерівність, якість трудового життя, гендерна сегрегація, гендерна дискримінація, гендерні стереотипи
This is an Open Access article, distributed under the terms of the Creative Commons Attribution 4.0 International license, which permits unrestricted re-use, distribution, and reproduction in any medium, provided the original work is properly cited. 


\section{ВСТУП}

В умовах сучасності гендерні проблеми активно впливають на якість трудового життя, істотно знижуючи іiі, що зумовлює актуальність дослідження даних проблем.

Так, на міжнародному рівні активно вживаються заходи щодо подолання гендерної нерівності. Зокрема у глобальних цілях сталого розвитку на 2016-2030 pp. ООН визначено важливість забезпечення гендерної рівності, розширення прав і можливостей всіх жінок. На фоні посилення економічної активності жінок в сучасному світі, в Україні спостерігається недостатня увага до гендерних проблем. Так, згідно Звіту із глобального гендерного розриву 2018 р. Світового економічного форуму (WEF), Україна в цьому рейтингу займає 65-е місце з 149 країн світу (61-е місце з 144 країн у 2017 році) [19], а отже має потребу в скороченні гендерного розриву.

Численні наукові заходи, нормативно-правові акти та державні проєкти так і не вирішили проблему гендерної диспропорції у оплаті праці, наданні прав та можливостей. Наслідками ігнорування гендерної проблеми можуть стати суттєві загальносуспільні втрати, нанесення шкоди людському добробутові, гальмування сталого розвитку.

Вирішення даної проблеми забезпечить жінкам гідну оплату праці, рівні можливості кар'єрного просування та ширшу автономність у прийнятті виробничих рішень, що $є$ важливими факторами високої якості трудового життя.

\section{1. ЛІТЕРАТУРНИЙ ОГЛЯА}

Дослідження якості трудового життя (далі ЯТЖ) з точки зору різних теоретико-методологічних підходів зумовило розбіжності у визначенні цього поняття.

Провідний український науковець Колот визначає ЯТЖ як «ступінь поєднання й односпрямованості умов трудового процесу та життя, задоволення співробітників стосунками в колективі і умовами праці» [9, с. 75]. Дійсно, поєднання даних параметрів формує високу якість трудового життя, в той час, як за умов існування гендерної нерівності працівники не можуть бути повною мірою задоволені умовами праці. 3 огляду на це визначення, існування гендерної нерівності буде мати негативний вплив на стосунки, умови праці, i, відповідно, на якість трудового життя.

В той час, як ЯТЖ в підході науковців Денвір і Хілладж визначається переважно такими індикаторами, як винагорода за працю, охорона та безпека здоров’я, використання та розвиток людських можливостей, зростання добробуту, соціальна інтеграція в організації праці, конституціоналізм, робочий простір, соціальна актуальність [5, с. 39]. Як бачимо, такі показники гендерної рівності, як справедлива оплата праці, рівні можливості є водночас і складовими якості трудового життя.

Браггард, Дюп'ї та ін. визначають якість трудового життя, як стан, який відчуває індивід в динамічному прагненні до своїх ієрархічно організованих цілей в сфері праці, за рахунок чого відбувається зменшення розриву, що відділяє індивіда від цих цілей, яке відображається як позитивний вплив на загальне функціонування суспільства [3, с. 39]. Як бачимо, зменшення розриву, в даному випадку співпадає 3 метою гендерної рівності, основними принципами якої $\epsilon$ відсутність асиметрії в оплаті праці та інших індикаторах гідної праці.

Аналізуючи наукові погляди на проблему впливу на гендерної нерівності на якість трудового життя, можна зазначити, що на сьогоднішній день існує велика кількість теорій, що досліджують негативний вплив гендерної нерівності на економічне зростання. Крім того, деякі дослідження вивчають саме взаємозв'язокміжгендерноюрівністюі економічним зростанням, тобтосамегендерну рівність, якпричину економічного зростання [4]. Отже, гендерна нерівність, знижуючи рівень економічного зростання, в кінцевому підсумку негативно впливає і на якість трудового життя, яка може бути забезпечена тільки високими показниками економічної і виробничої продуктивності. 
Більшість дослідників звертають увагу на значний гендерний розрив, зокрема в політичній сфері діяльності [10].

Існують дані про дискримінацію в оцінці трудового внеску жінки і чоловіка, в якій часто перевага віддається чоловікові при рівній компетентності і результатах праці [1].

Особливості гендерної асиметрії в оплаті праці грунтовно проаналізовано в дослідженні Лопушняк та Шандар, а також виокремлено напрями та розроблено пропозиції щодо забезпечення гендерного паритету в оплаті праці. Зокрема головними шляхами ліквідації гендерного розриву в оплаті праці чоловіків та жінок автори пропонують такі: просування «здорового» менталітету, що розірвав би замкнене коло нав'язаних статевих ролей; підвищення рівня обізнаності суспільства з приводу сучасних обов’язків та прав; підвищення підтримки з боку держави на адаптацію сільського населення до рівня цифрової економіки в країні та імплементація концепції гідної праці. В рамках виокремлених напрямів авторами запропоновано низку заходів, зокрема закріплення у виборчому законодавстві відповідних квот представництва всіх статей у парламенті пропорційно до частки кожного гендеру в структурі виборців України (у місцевих радах - пропорційно кількості виборців на певній території) [11]. Також запропоновано заходи дисциплінарного характеру, державні програми на основі відповідних критеріїв та показників тощо. Особливої уваги заслуговують пропозиції ввести у статистичну звітність спеціальне обстеження за професіями для створення відповідних динамічних рядів даних, що дозволили 6 провести більш компетентний аналіз щодо диференціації оплати праці за статевою ознакою. Погоджуючись 3 цим твердженням, ми пропонуємо визначити гендерно-чуттєві показники, які охоплюють гендерні зміни, що відбуваються в суспільстві в даний період часу і запровадити систему їх моніторингу.

Наявність дискримінації за статевою ознакою в економічній сфері на кожному етапі професійної діяльності відзначає Бережна. В своєму дослідженні вона виокремлює такі етапи: «зайнятість, оплата праці, добір, скорочення персоналу, просування на посаді, підвищення кваліфікації, відкриття власного бізнесу, тощо» [2].

Правовою основою для забезпечення гендерної рівності в Україні $є$ Конституція. Зокрема, у статті 24 Конституції зазначається: «рівність прав жінки та чоловіка забезпечується: наданням жінкам рівних 3 чоловіками можливостей у суспільно - політичній та культурній діяльності, в здобутті освіти та професійної підготовки, у праці та винагороді за неї...». Стаття гарантує рівність прав і свобод всім громадянам і відсутність обмежень за ознаками статі [16].

Гендерні відносини регулюються також різними законодавчими актами. Так, з метою встановлення рівності жінок і чоловіків у всіх сферах суспільної життєдіяльності було прийнято Закон України «Про забезпечення рівних прав і можливостей жінок і чоловіків» № 2866-IV. Статтею 16 Закону № 2866-IV встановлено, що «керівники органів державної влади та органів місцевого самоврядування зобов’язані забезпечити рівний доступ громадян до Державної служби та служби в органах місцевого самоврядування згідно кваліфікації та професійної підготовки незалежно від статі претендента» [17].

Формальний характер прийнятих в Україні законів, що стосуються теми гендерної нерівності, є ознакою гендерних проблем в правовій сфері. Так, багато законодавчих актів носять лише декларативний характер, і не містять конкретних норм і механізмів досягнення рівності за гендерною ознакою у сфері праці. Так, наприклад, жінки-інваліди, як цільова група, не згадуються в Державній програмі забезпечення рівних прав і можливостей жінок і чоловіків на період до 2021 року [6].

Таким чином, національне законодавство не відповідає сучасним вимогам і $€$ однією з детермінант таких явищ як гендерна дискримінація, гендерна професійна сегрегація та дисбаланс.

Хекман і Саттл, розглядаючи «якість трудового життя» як «ту міру, до якої члени виробничого підприємства можуть задовольнити свої основні особисті потреби за допомогою їх роботи на цьому підприємстві [7]. Даний підхід не враховує такий важливий аспект, як гендерна рівність. 
Отже, в процесі дослідження наукових праць сформовано власну думку щодо актуальності дослідження гендерної нерівності, як чинника впливу на ЯТЖ, а також визначено поняття ЯТЖ, як інтегральної характеристики, яка відображає співвідношення негативних та позитивних впливів соціальноекономічних, соціально-культурних факторів, що забезпечує гендерну рівність i, як наслідок, задоволеність працею.

\section{META}

Метою статті є оцінка гендерної нерівності в процесі реалізації трудового потенціалу та людського капіталу, обгрунтування позитивного впливу запропонованих заходів на якість трудового життя, соціальний клімат та економічний розвиток країни.

\section{3. МЕТОДОЛОГІЯ}

У статті використано такі наукові методи: статистичний (аналіз статистичних даних, опитувань громадської думки), абстрактно-логічний (огляд наукової літератури з даної теми), порівняння (співвідношення оплати праці за професійними групами), графічний (діаграма основних сфер зайнятості жінок в Україні за професійними групами), узагальнення (підбиття підсумків та підведення висновків).

\section{4. РЕЗУЛЬТАТИ}

Для визначення детермінант, що формують гендерну нерівність необхідно проаналізувати гендерні відносини на рівні реалізації трудового потенціалу та людського капіталу. В міжнародному аспекті проблема гендерної нерівності досліджуються на різних платформах. Так, у доповіді організації Об’єднаних Націй про людський розвиток 2019 року представлені значення і рейтинги індексу гендерної нерівності (Gender Inequality Index), який відображає гендерну нерівність за трьома вимірами - у сфері репродуктивного здоров’я, розширення можливостей і економічної активності. ІГН України в 2019 році становить 0.284, що ставить країну на 60 місце серед 189 країн [15]. Значення індексу знизилося на 7.2\% в порівнянні з показником 2005-го року (0.357). Цьому сприяла деяка активізація держави, особливо в правовій сфері, прийняття низки важливих для гендерної сфери законопроектів. Зазначимо, що ІГН не $€$ ідеальним методом для вимірювання гендерної нерівності. Він не включає інформацію про гендерні відмінності у використанні вільного часу, не враховує поділ професій на «жіночі і чоловічі» (гендерну сегрегацію) і розрив у заробітній платі за гендерною ознакою. Тому в статті досліджуються ці фактори та їх вплив на формування гендерної нерівності.

Вивчення можливих методів забезпечення гендерної рівності на рівні реалізації трудового потенціалу та людського капіталу автор пропонує вести в наступних напрямках:

- фактори, прояви, наслідки гендерної нерівності в Україні;

- основні проблеми у сфері зайнятості жінок;

- пошук основних напрямків вирішення проблеми гендерної нерівності в Україні.

Справедлива винагорода за працю є одним з найважливіших показників якості трудового життя. На державному рівні проводиться моніторинг основних показників гендерного паритету - співвідношення заробітної плати жінок і чоловіків. Так, за даними Державної служби статистики України протягом 20132018 років співвідношення середньої заробітної плати жінок та середньої заробітної плати чоловіків майже не змінилося, підвищившись усього на $0.3 \%$ (Рисунок 1), тобто в 2013-му році частка середньої заробітної плати жінок в склала 77.4\% від зарплат чоловіків, тоді як в 2018-му році цей показник знизився до $77.7 \%$, що на 1.1\% нижче за показник попереднього 2017-го року. 
Отже загалом ситуація не змінюється протягом п’яти років, демонструючи негативну динаміку за останній період.

Вищезазначені дані говорять про підвищення гендерного розриву в оплаті праці чоловіків і жінок не на користь жінок. Проаналізовані диспропорції зазвичай призводять до явища «фемінізації бідності», яке в свою чергу робить негативний вплив на репродуктивні та соціальні потреби жінок, істотно знижуючи їх якість життя. При цьому жінки часто позбавлені доступу до достатнього економічного ресурсу. Так, одночасно зі зниженням частки зарплати жінок в зазначений період відбулося зниження рівня їх зайнятості (Рисунок 2).

Як видно з Рисунка 2, в період з 2017-2018 рр. відбулося різке падіння рівня зайнятості як жінок, так і чоловіків, що пов’язано з соціально-економічною кризою в країні. Однак при цьому рівень зайнятості жінок залишався значно нижче аналогічного показника для чоловіків. У 2018-му році розрив між показниками для жінок і для чоловіків склав 9.9\%. Це вказує першочерговий напрямок докладання зусиль політики держави в забезпеченні гендерного паритету.

Крім того, для України є традиційним переважання зайнятості жінок зокрема у сфері послуг, торгівлі та некваліфікованої праці, а посади керівників і законодавців $є$ для них важкодоступними (Рисунок 3).

Отже, за даними Державної служби статистики України можна зробити висновок, що переважною професійною групою (22.6\%) серед зайнятих жінок в Україні в 2018 р. $є$ працівники сфери послуг і торгівлі. Позитивним явищем є збереження досить значної частки професіоналів (21.8\%) і фахівців (17.1\%). Далі йде група, що займає значну частку (18\%) - працівники некваліфікованої праці. Найбільш нечисленна професійна група серед зайнятих жінок в Україні (всього 6.1\%) - законодавці, вищі державні службовці, керівники. В той час, як переважна більшість жінок зайняті некваліфікованою працею, а також в сфері торгівлі та послуг. Для порівняння, частка законодавців, вищих державних службовців, керівників серед працюючих чоловіків становила в 2018 році 9.6\%, що на 3.5\% більше ніж жінок (Рисунок 4).

Аналізуючи дані державної служби статистики за 2018 р., можна зробити висновок, що частка чоловіків серед технічних працівників (40.1\%) значно перевищує аналогічний показник серед працюючих жінок (11.4\%). А у сфері торгівлі та послуг зайнято на 12.2\% чоловіків більше ніж жінок, що говорить про розподіл на традиційно жіночі та чоловічі професії, тобто про гендерну асиметрію серед працюючих.

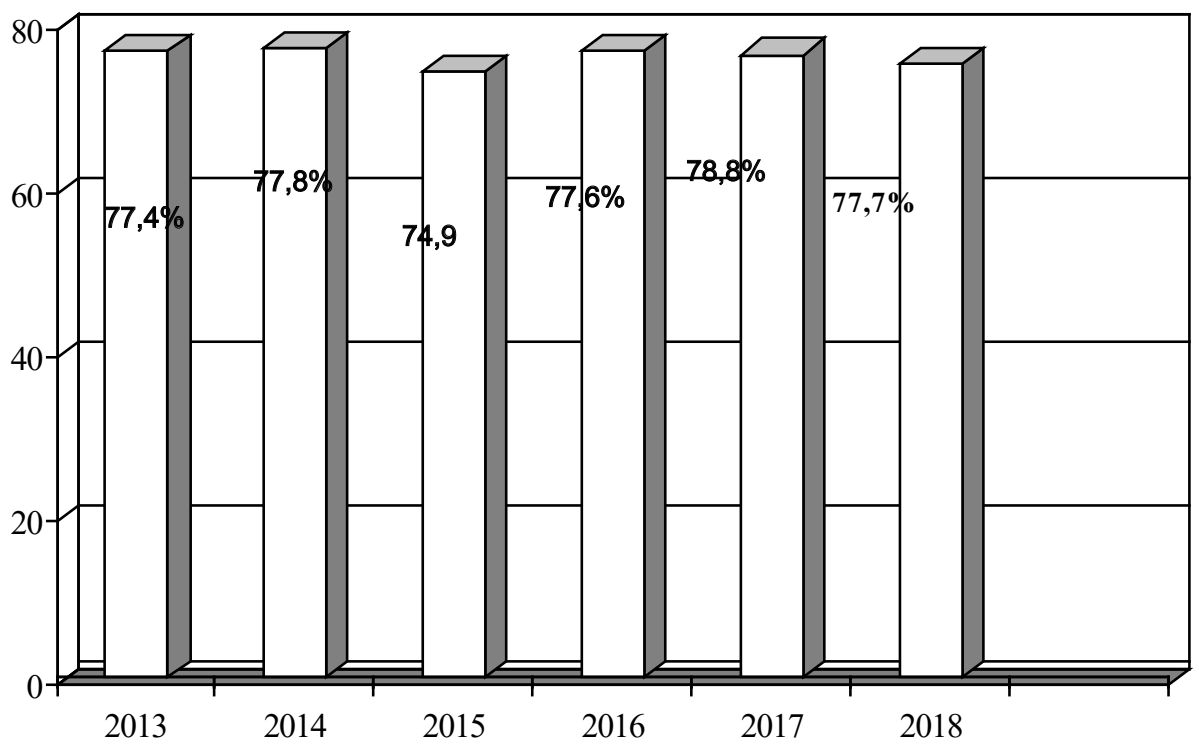

Джерело: Побудовано на основі [11].

Рисунок 1. Співвідношення заробітної плати жінок і чоловіків у 2013-2018 pp., \% 

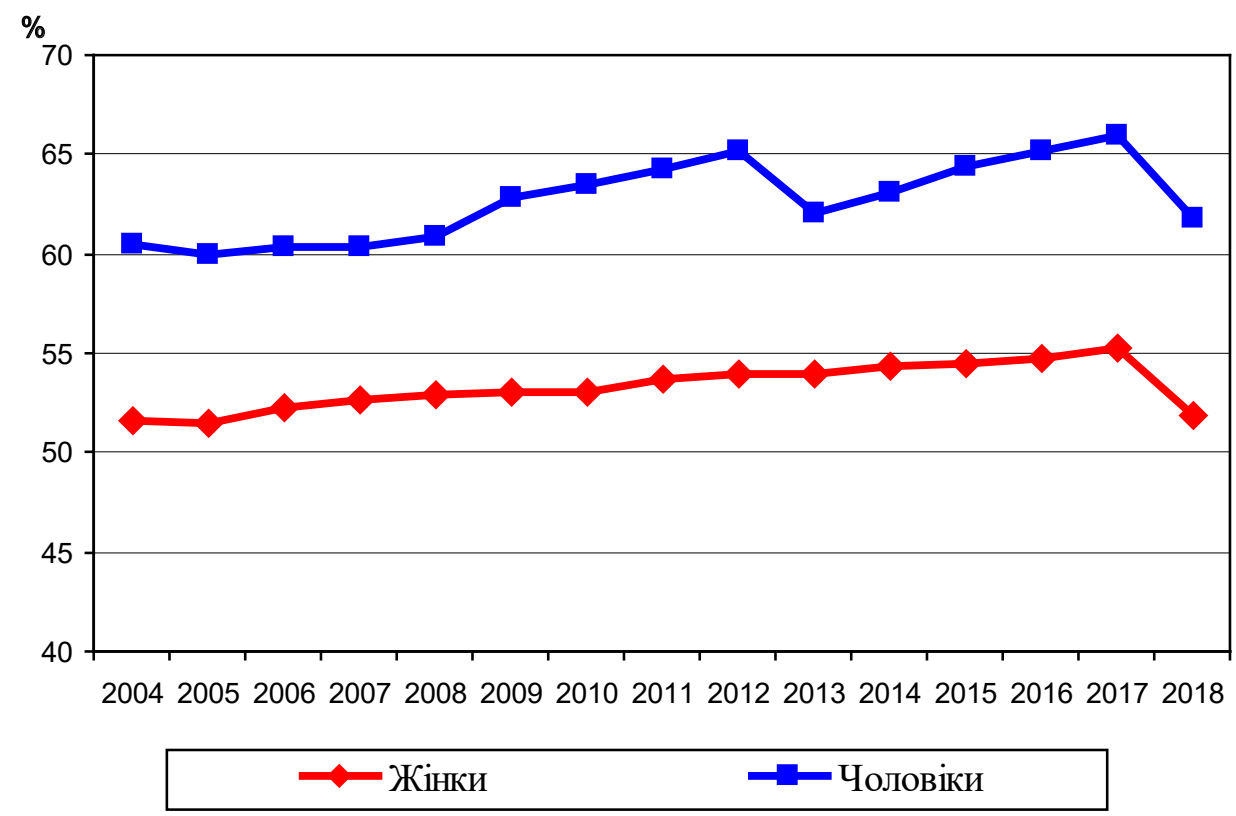

Джерело: Побудовано на основі [13].

Рисунок 2. Рівень зайнятості жінок і чоловіків у 2004-2018 pp., \%

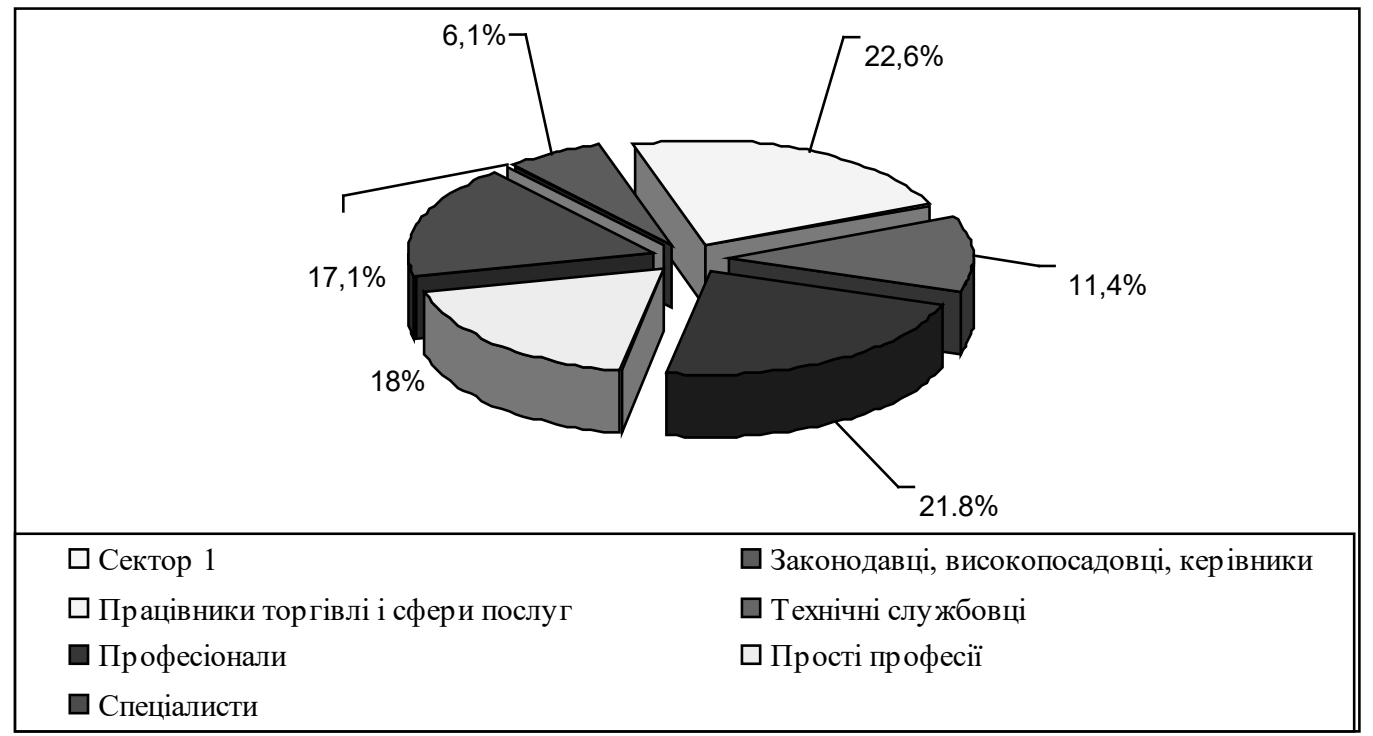

Джерело: Побудовано на основі [13] та власних розрахунків.

Рисунок 3. Основні сфери зайнятості жінок в Україні за професійними групами в 2018 р.

Беручи доуваги гендернуструктурузайнятості в Україні, розширеннязайнятостіжінокусфері управління та зайнятості чоловіків у соціальній сфері могло б зменшити рівень сегрегації. Але реальна ситуація із забезпеченням гендерної рівності в Україні свідчить про наявність гендерних диспропорцій. Так, у роботодавців різні очікування до досвіду роботи від претендентів різної статі. Зокрема, в пропозиціях 3 досвідом від 3 років домінують «чоловічі» вакансії. Пропозицій з найбільшим досвідом роботи вдвічі більше саме для чоловіків. Крім того, чималий досвід роботи - вимога високооплачуваних вакансій, яких більше для чоловіків. Однак, в даний момент в українському суспільстві саме на жінок традиційно покладається реалізація сімейних обов’язків, отже в більшості випадків жінки вибирають ті професії 


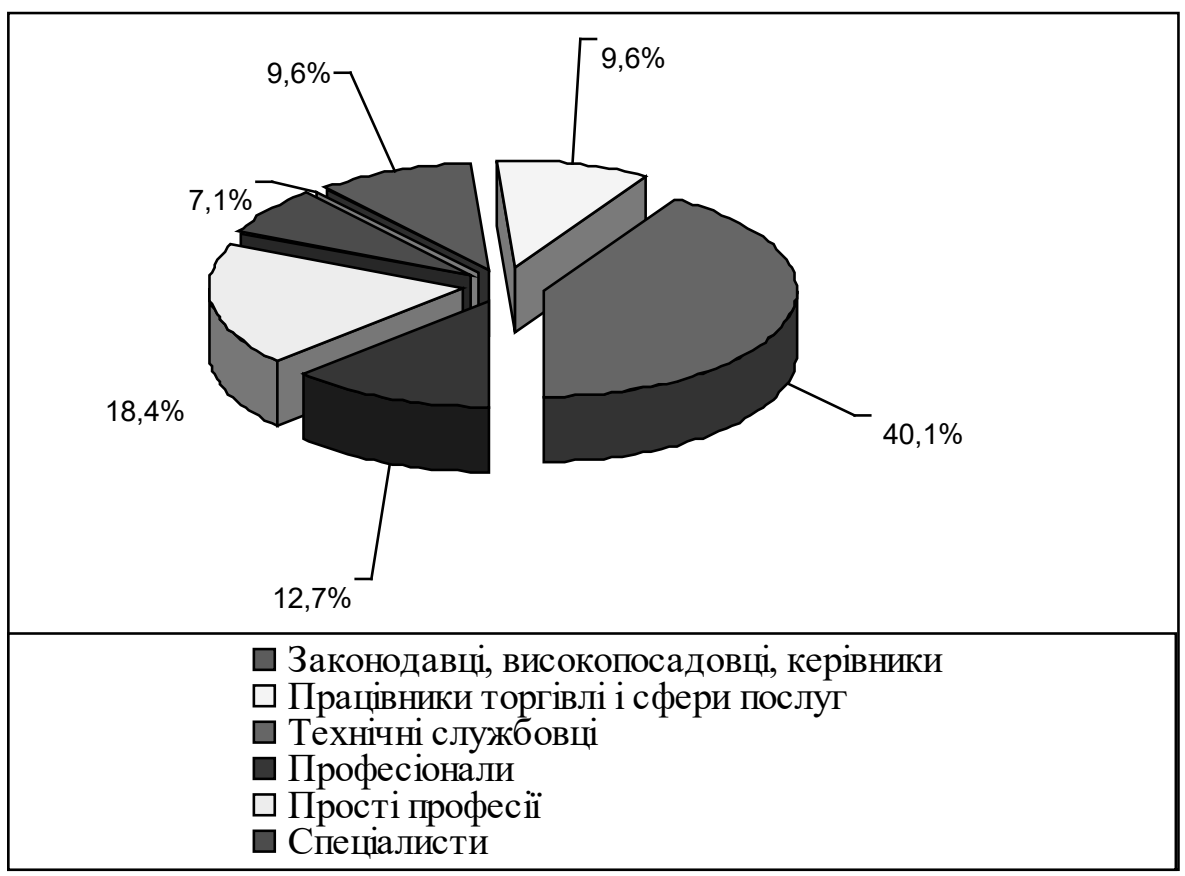

Джерело: Побудовано на основі [13] та власних розрахунків.

Рисунок 4. Переважаючі сфери зайнятості жінок в Україні за професійними групами у 2018 р.

і посади, які характеризуються меншим навантаженням і гнучкою зайнятістю і не вимагають високої інтенсивності праці. Така асиметрія призводить до виникнення «жіночих» професій, що перешкоджає професійному зростанню жінок і істотно знижує їх якість трудового життя. Чималу роль відіграє той факт, що жінки, з урахуванням домашньої праці працюють набагато довше, ніж чоловіки, що негативно впливає на якість їхнього життя. Так, в українському суспільстві традиційно присутній гендерний дисбаланс у розподілі домашніх обов’язків (Рисунок 5).

Так, за даними соціологічного опитування «дослідження участі жінок у складі робочої сили України» в 2012 р., близько трьох чвертей жінок відзначили, що саме вони переважно займаються у власному домогосподарстві прибиранням (78.4\% респондентів) і приготуванням їжі (75.3\% респондентів). Близько двох третин з числа жінок, які мають дітей або членів сім’ї, що потребують постійного догляду, відповіли, що турбота про цих людей відноситься саме до їх обов’язків. Більшість жінок також стверджували, що саме вони відповідають в сім’ї за купівлю продуктів і товарів повсякденного споживання.

Також за даними соціологічного опитування «дослідження участі жінок у складі робочої сили України» такі фактори, як «жіноча стать» та «наявність сімейних зобов'язань» посідають друге місце в рейтингу факторів дискримінації у сфері зайнятості. Майже до кожної десятої жінки-респондента упереджено ставились, доручаючи їй певне завдання або оцінюючи ï. Така ж кількість проінформувала про те, що траплялися випадки встановлення нижчої, в порівнянні з колегами, заробітної плати за роботу однакової цінності. Такі явища демотивують жінок, позбавляючи їх стимулів до праці. Як було сказано вище, одним із компонентів якості трудового життя є задоволеність працею. Отже, гендерна нерівність суттєво знижує ЯТЖ, призводячи в свою чергу до спаду мотивації та продуктивності праці. Таке становище знижує ефективність діяльності усієї організації.

Аналізуючи детермінанти такого явища, як гендерна нерівність можна зазначити, що однією з причин даного явища $є$ гендерний дисбаланс можливостей доступу жінок до гідної праці, що виражається в досить частих випадках відмови жінкам при прийомі на роботу внаслідок гендерних стереотипів. Як відомо, поняття «гідна праця» за змістом та за критеріями є досить близьким до поняття «якість трудового життя». Тобто за таких умов відбувається зниження якості трудового життя. 


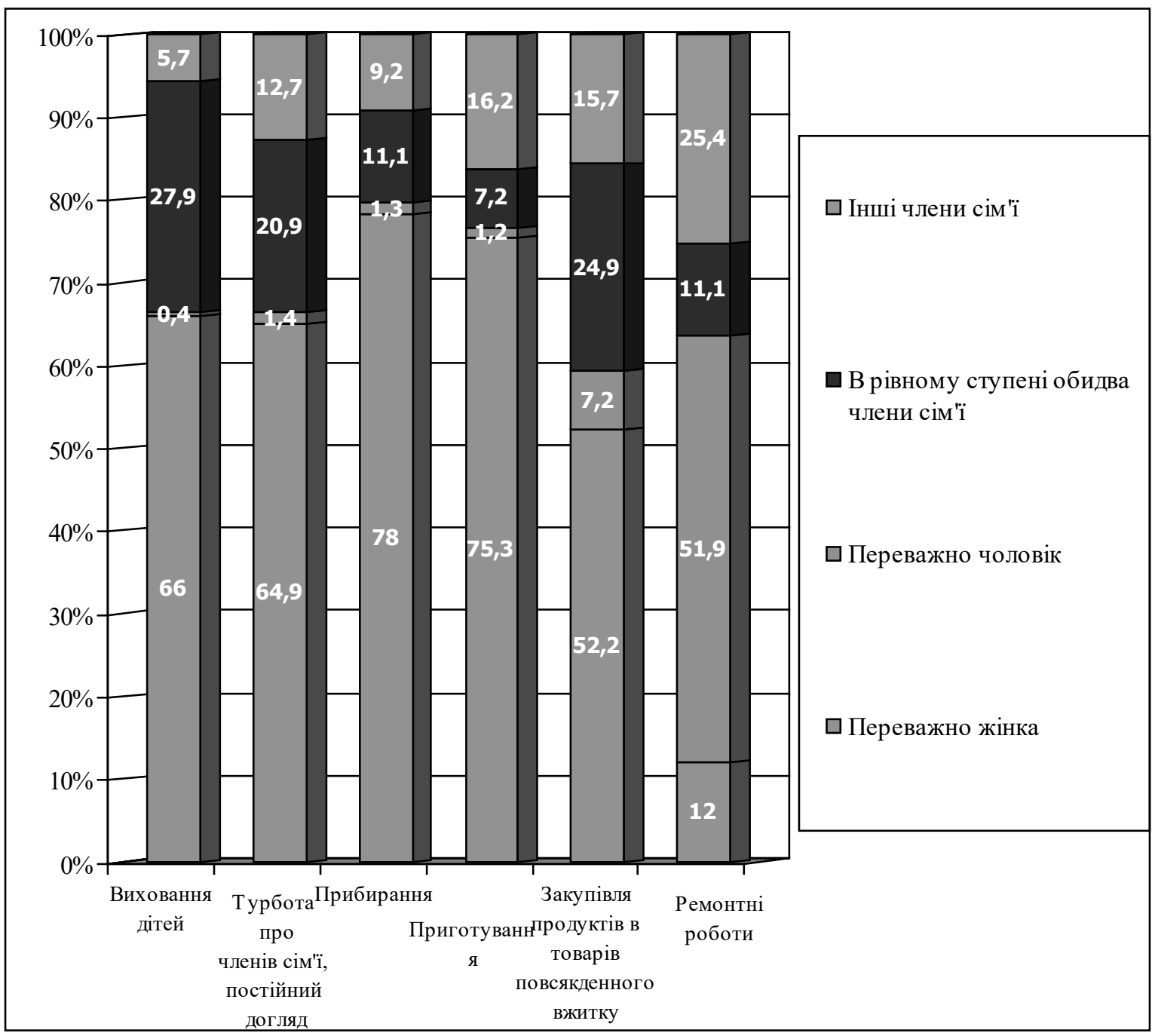

Джерело: Побудовано на основі [6] та власних розрахунків

\section{Рисунок 5. Особливості розподілу домашніх обов’язків у домогосподарствах України}

Існують також відмінності в якісних характеристиках зайнятості та соціальному статусі жінок і чоловіків. Жінки є власниками лише 22\% бізнес-структур та 6\% займають керівні посади у сфері великого бізнесу в Україні. Отже, їм важче отримати кредит, оскільки вони мають менше ресурсів, які вони можуть дати в заставу. Уряд не робить спеціальних зусиль з розширення доступу жінок до кредитів [14].

Розглядаючи зарубіжний досвід подолання проблеми, можна зазначити, що наприклад, в Литві комплексний гендерний підхід щодо реалізації норм гендерної рівності забезпечують такі інститути, як Європейський інститут гендерної рівності - орган ЄС, метою якого $є$ збір надійних даних з питання гендерної рівності, їх аналіз і висунення пропозицій. Міжміністерська комісія з рівних можливостей для чоловіків і жінок складається з представників усіх міністерств і двох департаментів. На цю структуру покладено основну відповідальність за реалізацію комплексного гендерного підходу. Комісія контролює виконання програм з гендерної рівності та реалізацію інших гендерно орієнтованих заходів. Вона вносить пропозиції щодо зміни існуючого законодавства, консультує уряд з питань гендерної політики. Комісія працює в тісній співпраці з іншими акторами національного механізму: омбудсменом з рівних можливостей, радником прем’єр-міністра, вченими та неурядовими організаціями. Крім реалізації комплексного гендерного підходу, ця структура $є$ значущою ланкою в налагодженні взаємодії між усіма частинами національних механізмів, включаючи не тільки державний, а й приватний сектор. Щорічно комісія звітує перед главою системи національних механізмів [18]. 
Отже, на нашу думку, Україні слід застосувати досвід таких країн, як Латвія і Литва, які успішно вирішують проблему гендерної нерівності. Ситуація ускладнюється тим, що сьогодні в системі державного управління відсутня структура, що має реальні повноваження з питань впровадження гендерної рівності. Після адміністративної реформи 2010-го року підрозділ, відповідальний за гендерну політику, було формально збережено, хоча його статус і функції залишалися невизначеними. Внаслідок цього впровадження гендерних підходів у систему державного управління відбувається вкрай неефективно.

Так, в Україні ще не налагоджена уніфікована система відстеження фінансування гендерної рівності. Це не дає можливості об’єктивно оцінити відповідну частку національного бюджету України.

Недостатня представленість жінок у соціологічних та економічних дослідженнях є значною частиною проблеми гендерної нерівності, яку необхідно вирішити в першу чергу, оскільки це дасть можливість виявити найбільш значущі диспропорції, що ведуть до гендерної нерівності. Тобто, необхідно сформувати гендерно-чутливу систему статистики, що відображає реальний стан на рівні реалізації трудового потенціалу та людського капіталу. Ї̈̈ відсутність призводить до гендерного дисбалансу. Але чи достатньо удосконалення одних лише перерахованих вище факторів для вирішення проблеми гендерної нерівності? Причини цього явища лежать в площині цінностей і культури суспільства. Низький рівень політичної гендерної культури в українському суспільстві, стійкі гендерні стереотипи - це перешкоди, які повинні бути подолані в першу чергу. Невідкладних заходів потрібно вжити, перш за все, на інституційному рівні, змінюючи ставлення до проблеми гендеру в суспільстві, трансформуючи поступово цінності гендерної рівності на рівень громадських організацій, трудових колективів і свідомості пересічного громадянина.

Отже, в результаті проведеного аналізу, факторами, що сприяють гендерній нерівності та зниження якості життя та ЯТЖ, як її складової, автор вважає відсутність в Україні на державному рівні:

- механізму аналізу та оцінки гендерної рівності;

- узгоджених зусиль держави, роботодавців та суспільства для досягнення гендерної рівності;

- цільового фінансування гендерних програм;

- гендерно-адекватної нормативно-правової бази.

Проявами гендерної нерівності внаслідок цього є такі явища, як гендерний розрив в оплаті праці жінок і чоловіків, гендерна сегрегація та дискримінація, зниження якості трудового життя і зниження ефективності діяльності організацій.

\section{ВИСНОВКИ}

У результаті проведеного дослідження можна зробити висновок, що на сучасному етапі в Україні немає механізму аналізу та оцінки гендерної рівності. В українському суспільстві все ще має місце прихована дискримінація, консервативні гендерні стереотипи, що пов'язують роль жінки виключно з сім'єю, а чоловіка - з громадською діяльністю. За таких умов відбувається зниження якості трудового життя жінок.

Отже для досягнення високого рівня якості трудового життя в Україні необхідно забезпечити:

- ефективний механізм аналізу та оцінки гендерної рівності, що включатиме введення до звітності статистичних даних, які відображають рівень гендерної рівності за допомогою гендерно-чутливих статистичних індикаторів;

- механізм контролю гендерно-чутливих статистичних даних у формі моніторингу на рівні організацій та на державному рівні;

- введення гендерної експертизи нормативно-правових актів у сфері праці на рівні держави;

- $\quad$ бюджетне планування з урахуванням гендерних аспектів;

- облік гендерних питань в діяльності міністерств праці, асоціацій роботодавців та профспілок;

- підвищення інформаційної грамотності населення в області гендерних проблем. 
Досягнення успішного вирішення проблем гендерної нерівності вимагає застосування сучасних інструментів гендерної політики. Державна статистика України не використовує гендерно-чутливі індикатори для вимірювання рівня нерівності. Врахування аспекту гендера у статистиці $є$ передумовою появи нових можливостей для досягнення гендерного балансу. Так, існує необхідність введення індикаторів, що пов’язані з витратами часу жінок і чоловіків, їх участь у неформальному секторі економіки, дані про домашнє насильство і сексизм на роботі, розподіл ресурсів, доход тощо.

Гендерна рівність є орієнтиром для України на шляху євроінтеграції. Інститути, що формують економічне життя суспільства в країні, повинні стати гендерно-орієнтованими. Рівні можливості і рівне ставлення у всіх сферах політичного, економічного і суспільного життя необхідні, щоб і чоловіки і жінки в рівній мірі мали високу якість життя і доступ до гідної праці. Це може дати можливість вирішити проблему гендерної нерівності та суттєво підвищити якість трудового життя та якість життя загалом.

\section{AUTHORS CONTRIBUTIONS}

Conceptualization: Ivan Riabokon.

Data curation: Ivan Riabokon.

Methodology: Ivan Riabokon.

Project administration: Ivan Riabokon.

Resources: Ivan Riabokon.

Supervision: Ivan Riabokon.

Writing - original draft: Ivan Riabokon.

Writing - review \& editing: Ivan Riabokon.

\section{СПИСОК ЛІТЕРАТУРИ}

1. Alksnis, C., Desmarais, S., \& Curtis, J. (2008). Workforce Segregation and the Gender Wage Gap: Is "Women's" Work Valued as Highly as "Men's"? Journal of Applied Social Psychology, 38, 1416-1441. https://doi.org/10.1111/j.1559-1816.2008.00354.x

2. Berezhna, H. (2019). Henderna (ne)rivnist u pidpryiemnytstvi v Ukraini ta sviti [Gender (in)equality in entrepreneurship in Ukraine and the world] (pp. 9-11). Gender policy of cities: history and modern times. (In Ukrainian). Retrieved from https://gc.kname.edu.ua/images/ docs/gengern_policy_2015/gend_policy_36.pdf

3. Bragard, L., Dupuis, D., Razavi, C., Reynaert, G., \& Etienne, A. (2012). Quality of work life in doctors working with cancer patients. Occupational Medicine (London), 62(1), 34-40. https://doi.org/10.1093/occmed/kqr149

4. Cuberes, D., \& Teignier, M. (2014). Gender Inequality and Economic Growth: a Critical Review. Journal of International Development, 26(2), 260-276. https://doi.org/10.1002/jid.2983

5. Denvir, A., Hillage, J., Cox, A., Sinclair, A., \& Pearmain, D. (2014). Quality of Working Life in the UK (Research Report 452$)$ (72 p.). Sector Skills Development Agency. Retrieved from https:/www.employment-studies.co.uk/system/files/resources/files/452.pdf

6. Government portal (2018). Pro zatverdzhennia Derzhavnoi sotsialnoi prohramy zabezpechennia rivnykh prav ta mozhlyvostei zhinok $i$ cholovikiv na period do 2021 roku [About the statement of the State social program of maintenance of equal rights and opportunities of women and men for the period till 2021]. (In Ukrainian). Retrieved from https://www.kmu.gov.ua/npas/pro-zatverdzhennya-derzhavnoyisocialnoyi-programi-zabezpechennya-rivnih-prav-ta-mozhlivostej-zhinok-i-cholovikiv-na-period-do-2021-roku

7. Hackman, J., \& Oldham, G. (2018). Work Redesign (330 p.). Massachusetts: Addison-Wesley.

8. Klasen, S. (2018). The Impact of Gender Inequality on Economic Performance in Developing Countries (Discussion Papers, No. 244). Retrieved from https://www.econstor.eu/bitstream/10419/176556/1/CRC-PEG_DP_244new.pdf

9. Kolot, A. (2008). Sotsialno-trudovi vidnosyny: teoriia i praktyka rehuliuvannia [Socio-labor relations: theory and practice of regulation] (230 p.). Kyiv: KNEU.

10. Libanova, E. (Ed.) (2012). Analytical research on women's participation in the labour force in ukraine (212 p.). Kyiv: UNFPA. Retrieved from https://cutt.ly/qh1JF3N

11. Lopushnyak, G., \& Shandar, A. (2019). Gender differentiation of payment for labor in Ukraine. Social and Labour Relations: Theory and Pr actice, 9(1), 1-13. Retrieved from http://dx.doi.org/10.21511/slrtp.9(1).2019.01

12. Martsenyuk, T. (2013). Gender Segregation of Labor Market: What Work Women and Men Are Looking for (hh.ua resume and vacancies database as case study). Commons Journal, 6, 89-95. (In Ukrainian). Retrieved from http://ekmair.ukma.edu.ua/handle/123456789/3790

13. State Statistics Service of Ukraine (n.d.). Pratsia Ukrainy [Labor of Ukraine]. (In Ukrainian). Retrieved from http://www.ukrstat.gov.ua/ druk/publicat/Arhiv_u/11/Arch_pu_zb.htm

14. Sychova, V., \& Honiukova, L. (2014). Gender Equality as Factor of Sustainable Social Development in Ukraine. State Formation, 1. (In Ukrainian). Retrieved from http://nbuv.gov.ua/UJRN/DeBu_2014_1_32 
15. United Nations Development Programme (2019). The Human Development Report (366 p.). Retrieved from http://hdr.undp.org/sites/ default/files/hdr2019.pdf

16. Verkhovna Rada of Ukraine (1996). Konstytutsiia Ukrainy [Constitution of Ukraine]. (In Ukrainian). Retrieved from https://www.president. gov.ua/documents/constitution

17. Verkhovna Rada of Ukraine (2005). Pro zabezpechennia rivnykh prav ta mozhlyvostei zhinok $i$ cholovikiv [On ensuring equal rights and opportunities for women and men]. (In Ukrainian). Retrieved from https://zakon.rada.gov.ua/laws/show/2866-15

18. Voronyna, O. (Ed.) (2008). Gendernoye ravenstvo v sovremennom mire. Rol natsionalnykh mekhanizmov [Gender equality in the modern world. Role of national machineries] (768 p.). Moscow: Maks-Press. (In Russian)

19. World Economic Forum (2018). The global gender gap report 2018 (367 p.). Retrieved from http://www3.weforum.org/docs/WEF_ GGGR_2018.pdf 